\title{
Study of Labor Intensity of Employees of the Department for Combating Drug Crime of the National Police of Ukraine
}

\author{
Sergii Korsun *1 [0000-0001-7634-0341], Yurii Orlov 2 [0000-0002-7656-9522], \\ Jozef Zatko 3 [0000-0001-8772-1385] \\ ${ }^{1}$ University of Modern Knowledge, Kyiv, Ukraine \\ ${ }^{2}$ Department of Combating Drug Crime of the National Police of Ukraine, Kyiv, Ukraine \\ ${ }^{3}$ European institute of further education, Podhajska, Slovak Republik \\ *korsun050@gmail.com
}

\begin{abstract}
The article is devoted to the study of labor intensity of employees of the Department for combating drug crime of the National Police of Ukraine. The intensity of work of employees of this department has not yet been studied by domestic scientists, which determined the importance and relevance of our research. In the course of the research, we analyzed scientific sources and regulatory legal acts concerning the definition of the concept of "labor intensity" and scientific and methodological approaches to the practical definition of labor intensity of various categories of employees. For the study, a methodology for determining the labor intensity of employees was selected, compiled in the form of a questionnaire containing ten characteristics of the work performed. Employees of the Department for combating drug crime were involved as experts. Experts evaluated each individual activity characteristic on a four - point scale: 1 point - not expressed; 2 points - weakly expressed; 3 points - expressed; 4 points - strongly expressed. The average total assessment of labor intensity of employees of the Department for combating drug crime of the National Police of Ukraine is determined at the level of $29 \pm 3.6$ points. According to the existing classification for assessing labor intensity, tension over 23 points makes it possible to classify the work of employees of the Department for combating drug crime as "very stressful". In addition, the survey determined that the activities of employees of this professional group mainly take place in three forms, namely: interpersonal communication (on average takes about $44 \%$ of working time), search activities (on average takes about $25 \%$ of working time) and working with documents (on average takes about $31 \%$ of working time).
\end{abstract}

Keywords: labor intensity, very intensive work, forms of activity, interpersonal communication, search activities, work with documents, Department for combating drug crime.

\section{INTRODUCTION}

The current state of scientific research in the field of labor psychology gives grounds to assert that scientists have accumulated a significant array of empirical data on various psychophysiological manifestations of employees in various fields of activity. Special attention of researchers is focused on employees of extreme professions, professions related to dangerous and risky [1, 2] activities, because it is in the professional activities of employees of these professions that stressful situations and situations of stress disorders are more often observed than others. It is these professions that require constant psychological support, implementation of psychologists and psychological support units into the organization structure. The vast majority of extreme professions include security and defense professions. The study of the relationship between the characteristics of employees'activities and the resulting stress disorders made it possible to identify some of the root causes of stress and stress disorders. It is proved that one of the basic psychophysiological causes of stress and stress disorder is the state of activity tension. The nature of the functioning of those body systems that ensure the activity of the physiological and psychological components of the individual allows us to identify systemic grounds for differentiating States of tension. The predominance of 
cognitive or emotional-activation components determines the development of emotional or operational tension, and the principle based on the analysis of changes in the psychophysiological price of activity allows us to distinguish between productive and unproductive forms of tension.

By resolution of the Cabinet of Ministers of Ukraine No. 322 of April 29, 2020, the interregional territorial body of the National Police - the Department for combating drug crime-was established as a legal entity of public law. The intensity of work of employees of this department has not yet been studied by domestic scientists, which determines the importance and relevance of our research.

\section{RESEARCH ANALYSIS}

It should be noted that scientific studies of labor intensity of employees of extreme professions and employees of the security and defense sector on the territory of Ukraine were conducted quite rarely and not all professions were properly studied in terms of determining labor intensity.

Ukrainian scientists Korsun S. and MaidikovYu. studied the labor intensity of employees of operational divisions of the Tax Police [3]. In the monograph "Psychology of Activity of Tax Police Officers" Tkachuk T. and Korsun S. also paid attention to the study of labor intensity [4]. Labor intensity as a factor affecting the reliability of criminal police officers was studied by $\mathrm{V}$. Krivolapchuk [5]. Scientific works of N. Naenko are devoted to the study of mental tension on the territory of the Russian Federation [6].

Along with this, scientistsHong Z., Long Y., Ming G., Daqing G. were studied the labor intensity of railway locomotive drivers [7]. The mental mechanisms of close attention, which are directly related to labor intensity, were studied by scientists Langner, R., Eickhoff, S. B. [8]. Scientists Young M., Brookhuis K., Wickens C., Hancoc P. paid attention to the study of mental load in ergonomics [9].

\section{THE PURPOSE OF THE PAPER}

The goal of our research is to analyze the existing approaches to determining the labor intensity of employees of extreme professions and the sphere of security and defense, select and use existing methods to determine the labor intensity of employees of the Department for combating drug crime of the National Police of Ukraine.

\section{THE MAIN MATERIAL}

Order No. 248 of the Ministry of health of Ukraine dated April 08, 2014, along with other harmful industrial factors, defines labor intensity. Labor intensity is a characteristic of the labor process that reflects the load mainly on the central nervous system, sensory organs, and emotional sphere of the employee. Indicators that characterize labor intensity include: intellectual, sensory, emotional loads, the degree of monotony of loads, and the mode of operation [10].

It is known that any work activity can be characterized by three aspects:

- direct load (mental or physical), that is, certain requirements of the profession, the labor process to the employee;

- features of working conditions and the production environment in which the labor process is carried out;

- functional stress of the body, which manifests itself as an integral response of the body to the production load.

It is the integral response of the central nervous system to the production load that is the indicator that characterizes labor intensity. In accordance with the characteristics of the production load in the course of professional activity, tension can occur in one or more physiological systems of the employee's body. At the same time, one of these systems can be the main, working, and the rest - support systems, auxiliary. So, with heavy physical work, a significant load falls on the neuromuscular system, and the respiratory and cardiovascular systems ensure and maintain the normal functioning of the muscular system. When performing operator work in tracking mode, the visual analyzer and attention function are in a state of tension. Human labor activity associated with solving complex intellectual problems is characterized, first of all, by a high level of psycho-emotional stress, which causes an increased level of activity of the nervous and cardiovascular systems.

Any work involves the presence of a certain load; however, not every load presents difficulties that cause some kind of stress. Load is an objective category, and difficulty is something that is associated with the subjective and objective capabilities of an individual [11].

Performing any activity requires certain efforts from the employee and an optimal amount of psychoemotional stress, in which the body's reactions are the most perfect and effective. In this functional state, attention and memory are sharpened, perception processes improve, and reaction speed increases. Thus, any work, if it is optimal in intensity and duration and takes place in favorable production conditions, has a fruitful effect on a person, contributes to his improvement, the development of certain professional skills and abilities. However, if the work is excessive in duration or intensity of physical and mental stress, then the tension of various functional systems of the body increases, fatigue develops, leading, at first, to a decrease in performance and deterioration of well-being. In the future, excessive production load can lead to stress disorders and the development of chronic diseases. 
It should be noted that fatigue in its biological essence is a normal physiological process that plays an appropriate protective role in the body, preserves its individual systems and organs from excessive stress. A certain level of fatigue at the end of work activities is even necessary, since it helps to maintain the achieved state of fitness of the body for work load. Fatigue can manifest itself in the following manifestations:

- reduction of labor intensity (productivity, efficiency) while maintaining the initial stress of physiological functions;

- an increase in the degree of stress of physiological systems with constant indicators of the quality and quantity of the volume of work performed;

- some deterioration of performance with a simultaneous increase in the degree of stress of physiological functions.

It is quite clear that in the last two cases, fatigue by the end of work will be deeper (it can be called overwork) and to restore the optimal functional state of the most stressful systems in the process of activity, the employee's body will need a much longer rest. When the level of stress of individual functions exceeds the physiological capabilities of these systems or organs and may seem excessive, in such cases, unfavorable changes occur that lead to a decrease in the body's energy reserves, disorders, and sometimes to the occurrence and development of diseases.

In addition to the fatigue factor, an important role is played by the emotional component, which is almost always present in work and contributes to the formation of nervous and emotional tension. Its level is closely related to both the specifics of the activity and the individual response to these features. However, almost always psychoemotional tension occurs when it is necessary to make decisions, especially in conditions of lack of time and high personal responsibility.

The degree of tension and its accompanying shifts in the employee's body largely depend on motivation. Some semantic characteristics of the activity, such as high significance, danger, competition, etc., also lead to emotional tension. Depressed mood, work without desire, troubles, stressful situations adversely affect the effectiveness of the labor process. Negative emotions contribute to nervous overstrain and premature fatigue. In the case of prolonged and constant action, the return to normal functional state becomes extremely difficult and prolonged. The chronic impact of emotional stress on the employee's body is also a factor contributing to the development of excessive body tension. In such cases, it is possible to "break" the regulatory mechanisms. As a result, the nervous, cardiovascular and other systems, as well as mental functions, receive additional stress, and are forced to work in unbearable modes.
Thus, the stress of the human worker's body causes not only the production load itself, leading to the development of fatigue, but also causes complex sociopsychophysiological reactions that significantly increase the load. In relation to the labor process and the special conditions of its course, tension acts not as a direct result of these conditions, but as a direct integral reflection of the situation in which the activity is performed that is significant for the subject.

Unfavorable factors that increase the tension of the employee's body and, accordingly, labor intensity include the following:

- lack of time or information to make a decision;

- difficulties of the problem situation;

- physiological discomfort, that is, non-compliance of working conditions with sanitary and hygienic standards;

- dangerous operating conditions;

- increased significance of erroneous actions;

- the presence of serious obstacles in the activity;

- underloading or overloading of information;

- conflict situations;

- increase the pace of activity;

- introduction of competition elements;

- joint activities of two or more persons;

- hypokinesia.

Labor intensity also occurs under the influence of non-specific factors. This refers to unfavorable working conditions and environmental parameters in the workplace that cause discomfort, distract from the performance of basic functional duties that require a certain strain of physiological functions.

To denote the state of a person in severe or extreme conditions of activity, researchers use various concepts: tension, stress, nervous and emotional tension of the body, and so on, although no one doubts the fact that the high physiological cost of tension has both the effect of direct influence, which reduces performance, and longterm consequences that can lead to injuries, as well as the occurrence and development of diseases [11-16].

The mental state of tension is multifaceted. Along with emotional and motivational processes, perceptual, intellectual, mnemic and motor processes also play an important role in the development of psychological stress [4].

This circumstance prompted some authors to emphasize the predominant involvement of certain mental processes when classifying types of tension. Investigating psychological problems of readiness for 
activity Dyachenko M. and Kandybovich L. [17] distinguish the following types of mental tension:

- perceptual, which occurs, for example, in the case of increased difficulties in perceiving the necessary information;

- intellectual - if it is impossible to find an adequate solution or way out of a critical situation;

- emotional - when emotions arise that disorganize the activity;

- strong-willed - when a person is unable to show conscious efforts and master the situation;

- motivational - related to the struggle of motives, for example, to fulfill your duty or avoid danger and risk.

The research conducted by N. Naenko allowed us to distinguish two types of mental tension, one of which was called operational, and the other - emotional. The state of operational tension is a relatively neutral approach to the business process. In contrast, the state of emotional tension is characterized by subjective experiences in the course of activity, an evaluative, emotional attitude of a person to the conditions of its course. Along with the consideration of the concepts of tension in the psychological aspect, this term is widely used both to characterize the process of labor activity itself, and to denote specific states that arise during its implementation [6].

The degree of activity intensity can be directly determined by the structure of the labor process, in particular, the content of the workload, its intensity, saturation of activities, and so on. In this sense, tension is interpreted from the point of view of the requirements imposed by a particular type of work on a person [18]

Taking into account the variety of points of view and the incompleteness of the development of this problem, in our study we will adhere to the definitions that are most often used in the psychology and physiology of work. Thus, the dictionary of physiological terms [19] provides the following interpretation: "Working stress is a change in the human state and functional systems of the body that occurs under the influence of work." Labor intensity should be understood as ergonomic conditions and the nature of work (professionographic criteria), which, acting on a person, cause tension in the functional systems of the body [20].

The variety of works that require different stress of the functional systems of the body puts forward an urgent need to classify them, enter information into a systematized number of classes, and therefore scientists pay great attention to this issue. The development of methods and criteria for assessing the severity of labor (for physical labor professions), as well as labor intensity, is one of the most pressing problems. The relevance of this problem is also due to the fact that differences in the severity and intensity of work serve as one of the objective criteria that should be taken into account when distributing social benefits, in particular, the duration of vacations, salary levels, setting the retirement age, and so on.

At the current stage of reform and formation of the national police system, there is a sharp increase in information and emotional stress on employees, complications of interpersonal relations and relations with citizens. At the same time, the company imposes increased requirements on employees of all levels of the law enforcement system. These requirements are particularly important in relation to police officers, since the activities of police officers take place in harsh conditions of the exercise of power, clashes with the shadow sides of life associated with the use of weapons. In extreme situations, an employee of the Department for combating drug crime needs to instantly assess the situation, make the right decision and at the same time have adequate behavior. The conditions of social tension that are characteristic of the entire society as a whole require employees of the Department for combating drug crime to maintain a high degree of combat readiness and efficiency, and this is achieved at the cost of significant nervous and emotional psychological stress.

The study of labor intensity of employees of the Department for combating drug crime and the conclusions drawn as a result of the study may be of real practical interest. The results obtained can be recommended for their use in the system of professional and psychological selection in the divisions of the Department for combating drug crime, can be used by full-time psychologists, employees of the departmental medical service and employees of personnel support units.

In order to objectify the assessment of labor intensity of employees of the Department for combating drug crime of the National Police of Ukraine, we conducted a survey of operational employees of the Department. The experts were operational employees of the Department for combating drug crime and territorial (separate) divisions in the regions. 63 people took part in the survey. The following characteristics of the work process were included in the questionnaire:

- degree of responsibility in the work;

- the need to make responsible decisions;

- degree of workload;

- overtime work;

- irregular workload;

- lack of time;

- organization of work;

- the presence of stressful situations; 
- duration of stressful effects;

- lack of motor activity (hypokinesia).

Each characteristic was evaluated by experts in the range from one to four points, depending on the severity. The definition of the labor category was carried out based on the results of the total assessment and compared with the distribution data:

- up to 16 points - little stressfulwork;

- from 17 to 22 points - stressfulwork;

- more than 23 points is very stressful work.

The data obtained made it possible to determine the average total assessment of labor intensity of employees of the Department for combating drug crime of the National Police of Ukraine at the level of $29 \pm 3.6$ points. A certain point characteristic, according to the existing classification for assessing labor intensity, allows us to classify the work of specialists of the studied professional group as "very stressful".

Along with the study of labor intensity, an analysis of the activities of an employee of the Department for combating drug crime of the National Police of Ukraine was also carried out and the predominant forms in which this activity is carried out were found out. It was found that the activities of these employees occur mainly in three forms, namely: interpersonal communication, search activities, and work with documents. Let's take a closer look at each of the forms.

Interpersonal communication: communication; conversations; getting explanations; executing orders of an investigator, inquirer, prosecutor; communication with experts, specialists, working with confidential and other sources of information (according to experts, such work on average takes about $44 \%$ of the working time of an employee of the Department for combating drug crime of the National Police of Ukraine).

Search activities: surveillance; operational documentation; inspection of objects; making inquiries; preparation and implementation of operations to detain persons suspected of committing crimes or wanted (take up about $25 \%$ of working time).

Working with documents: getting acquainted with materials and instructions; processing responses, references, plan schemes, current documentation; maintaining operational records (takes approximately $31 \%$ of working time).

\section{CONCLUSIONS}

Thus, based on our research, we determined that the labor intensity of employees of the Department for combating drug crime of the National Police of Ukraine is quite high and should be classified as "very tense". It is known that the effectiveness of any work activity depends on many factors. An employee's activity will be effective when that employee performs the functions assigned to them reliably, without errors or failures in their work. Labor intensity has a significant impact on efficiency and reliability. The more stressful the activity, the more likely it is that employees will make mistakes and fail. When performing professional selection of employees for positions in the divisions of the Department for combating drug crime, it is necessary to take into account the appropriate psychophysiological professionally important qualities that will allow the employee to carry out their professional activities in conditions of tension reliably and without fatal mistakes.

So, labor intensity is one of the factors that places increased demands on the psychophysiological reliability of a person as an employee. This is especially evident in professions that belong to the category of "very stressful", or they are also called extreme professions. And employees of the Department for combating drug crime of the National Police of Ukraine represent exactly this category, which is empirically proven by our research.

Studies of extreme professions show that in order for employees of this profession to show good skills, knowledge, physical qualities and professionally important psychological qualities, they must work in a scientific, rational, standardized operating system of the organization [21]. Thus, the need for standardization, rationalization and scientific organization of work should also be taken into account in the work of employees of the Department for combating drug crime of the National Police of Ukraine.

We also investigated and established the percentage differentiation of working hours of employees of the Department for combating drug crime of the National Police of Ukraine. It was found out that the activities of employees of this professional group mainly take place in three forms, namely: interpersonal communication (such work on average takes about $44 \%$ of working time), search activities (such work on average takes about $25 \%$ of working time) and work with documents (such work on average takes about $31 \%$ of working time).

Scientific studies show that excessive labor intensity and intense psychological overload are the cause of accidents at work [22]. Studying the differentiation of the distribution of working hours of employees of the Department for combating drug crime and the intensity of their activities, we can finally state the need for a scientific approach to the organization of work of this category of employees. 


\section{REFERENCES}

[1] Korystin, Oleksandr and Svyrydiuk, Nataliia (2020), "Methodological principles of risk assessment in law enforcement activity", Nauka i Pravookhorona, vol. 3 (49), pp. 191-198. DOI: $10.36486 / n p .2020 .3(49) .19$

[2] Korystin, Oleksandr and Svyrydiuk, Nataliia (2021), "Activities of Illegal Weapons Criminal Component of Hybrid Threats", Proceedings of the International Conference on Economics, Law and Education Research (ELER 2021), Series: Advances in Economics, Business and Management Research, vol.170, 22 March, pp. 8691. DOI: 10.2991/aebmr.k.210320.016

[3] Korsun, S. Maidikov, Y. (2010), Profesiinyi vidbir pratsivnykiv operatyvnykh pidrozdiliv podatkovoi militsii: psykholohichni zasady, monohrafiia, Korosten, Ukraina.

[4] Tkachuk, T. and Korsun, S. (2013), Psykholohiia diialnosti pratsivnykiv podatkovoi militsii, monohrafiia, Kyiv, Ukraina.

[5] Kryvolapchuk, V. (2011), "Psykhofiziolohichna nadiinist pratsivnykiv kryminalnoi militsii", Pivdennoukrainskyi chasopys, vol. 4, available at: http://dspace.pdpu.edu.ua/bitstream/123456789/12 048/1/Krivolapchuk\%20V\%202011.pdf

[6] Naenko, N. (1976), "Psykhycheskaia napriazhennost", SSSR, Moskva, Rossiia.

[7] Hong, Z. Long, Y. Ming, G. and Daqing, G. (2016), "The Effectof EMU Driver Operating Timeon Professional Psychological Quality", Periodica Polytechnica Transportation Engineering, vol. 44(4), pp. 235-243. DOI:10.3311/PPtr.9224

[8] Langner, R. and Eickhoff, S.B. (2013), "Sustaining Attention to Simple Tasks: A Meta-Analytic Review of the Neural Mechanisms of Vigilant Attention", Psychological Bulletin, vol. 139 (4), pp. 870-900. DOI: $10.1037 / \mathrm{a} 0030694$

[9] Young, M.S. Brookhuis, K.A. Wickens, C.D. and Hancock, P.A. (2015), "State of science: mental work loadinergonomics", Ergonomics, vol. 58 (1), pp. 1-17. DOI: 10.1080/00140139.2014.956151

[10] Pro zatverdzhennia Derzhavnykh sanitarnykh norm ta pravyl "Hihiienichna klasyfikatsiia pratsi za pokaznykamy shkidlyvosti ta nebezpechnosti faktoriv vyrobnychoho seredovyshcha, vazhkosti ta napruzhenosti trudovoho protsesu": Nakaz Ministerstva okhorony zdorovia Ukrainy vid
08.04.2014 № 248, available at: https://zakon.rada. gov.ua/laws/show/z0472-14\#Text

[11] Bornevasser, M. (1994), "Stress v uslovyiakh truda", Ynostrannaia psykholohyia, vol. 2, no 1 (3), pp.44-51.

[12] Sherman D. (1976), «Osnovy psikhofiziologiii vrachebnogo kontrolya v parashyutnom sporte», SSSR, Moskva, Rossiia.

[13] Javier González Marqués and Carlos Pelta (2013), "PSICO-A: A Computational System for Learning Psychology", IJMECS, vol. 5, no. 10, pp. 1-8. DOI: $10.5815 /$ ijmecs.2013.10.0

[14] Prashant M. Dolia (2013), "Evaluation: The New Philosophical Roles \& Psychological Means", IJMECS, vol. 5, no. 7, pp. 34-40. DOI: $10.5815 /$ ijmecs.2013.07.04

[15] Mritunjay Rai, R.K.Yadav, Agha A. Husain, Tanmoy Maity and Dileep K. Yadav (2018), "Extraction of Facial Features for Detection of Human Emotions under Noisy Condition", IJEM, vol. 8, no. 5, pp.49-62. DOI: 10.5815/ijem.2018.05.05

[16] Ashima Aggarwal and Gour Sundar Mitra Thakur (2014), "Design and Implementation of Fuzzy Rule Based Expert System for Employees Performance Appraisal in IT Organizations", IJISA, vol. 6, no. 8, pp.77-86. DOI: 10.5815/ijisa.2014.08.09

[17] Dyachenko, M. and Kandybovich, L. (1976), "Psychological problems of readiness for activity", BSSR, Minsk.

[18] Leonova, A. (1984), "Psikhodiagnostika funktsional'nykh sostoyaniy cheloveka", SSSR, Moskva, Rossia.

[19] Slovar' fiziologicheskikh terminov (1987), SSSR, Moskva, Rossiia.

[20] Printsipy kompleksnoy otsenki napryazhennosti truda I rabochego napryazheniya pri umstvennykh vidakh deyatel'nosti: metod. rekomendatsii (1986), NII Meditsiny truda, SSSR, Moskva, Rossiia.

[21] Zhou, H. (2010), Research on Effect of EMU driver's Operating Time on Professional Psychological Quality, Master Thesis of Beijing Jiaotong University, China, available at: http://www.dissertationtopic.net/doc/664394

[22] Huang, J. (2020), "Studyonship officer1's labor intensity and duty arrangement", Maritime Safety \& Environment Management Dissertations, available at: https://commons.wmu.se/msem _dissertations/339 